SHORT COMMUNICATION

\title{
First description of the worker of Planicapritermes longilabrum with notes on the nest of Planicapritermes planiceps (Blattaria: Isoptera: Termitidae)
}

\author{
Rayssa ALMEIDA-AZEVEDO* (), Renato Almeida de AZEVEDO, Rafael SOBRAL, \\ José Wellington de MORAIS \\ Instituto Nacional de Pesquisas da Amazônia - INPA, Coordenação de Biodiversidade - COBIO, Av. André Araújo 2936, Petrópolis, 69083-000, Manaus, AM, Brazi \\ * Corresponding author: rayssa.a.azevedo@gmail.com; (D) https://orcid.org/0000-0003-2045-3878
}

\section{ABSTRACT}

Planicapritermes Emerson, 1949 is a South American termite genus with two nominal species: Planicapritermes planiceps (Emerson, 1925) and Planicapritermes longilabrum Constantino, 1998. The soldiers of this genus are characterized by strongly asymmetrical mandibles. Planicapritermes planiceps was described from soldiers and workers, and P. longilabrum only from soldiers. Here we describe and illustrate workers of $P$. longilabrum based on specimens collected in Rondônia state, Brazil. We also present a comparison between workers and soldiers of $P$. planiceps and $P$. longilabrum, and describe the nest of $P$. planiceps.

KEYWORDS: Amazon forest, gut anatomy, taxonomy, termites

\section{Primeira descrição dos operários de Planicapritermes longilabrum, com notas sobre o ninho de Planicapritermes planiceps (Blattaria: Isoptera: Termitidae)}

\section{RESUMO}

Planicapritermes Emerson, 1949 é um gênero de cupins da América do Sul com duas espécies nominais: Planicapritermes planiceps (Emerson, 1925) e Planicapritermes longilabrum Constantino, 1998. Os soldados deste gênero são caracterizados por ter mandíbulas fortemente assimétricas. Planicapritermes planiceps foi descrita com base em soldados e operários, e $P$. longilabrum somente em soldados. Aqui nós descrevemos e ilustramos os operários de P. longilabrum com base em espécimes coletados em Rondônia, Brasil. Também comparamos operários e soldados de $P$. planiceps e $P$. longilabrum, e descrevemos o ninho de P. planiceps.

PALAVRAS-CHAVE: Floresta Amazônica, anatomia intestinal, taxonomia, térmita

Termitinae is one of the four subfamilies of Termitidae in the Neotropical realm, with 105 living, and five fossil species (Constantino 2019). Some genera of Termitinae are characterized by having soldiers with asymmetrical mandibles, such as Neocapritermes Holmgren and Planicapritermes Emerson (Constantino 1999). The soldier of Planicapritermes is morphologically more similar to the soldier of Neocapritermes than to any other Termitinae genus. This similarity has been explained in a recent phylogenetic study, in which these two genera are considered sister groups (Bourguignon et al. 2017).

Planicapritermes was described by Emerson (in Snyder 1949) to accommodate a single South American species, $P$. planiceps, previously included in the subgenus Neocapritermes of the genus Capritermes (Constantino 1998). Posteriorly, Neocapritermes had its status changed to genus in Snyder's
(1949) catalog, and Constantino (1998) described Planicapritermes longilabrum. The genus is characterized by soldiers with dorso-ventrally flattened heads in addition to the strongly asymmetrical mandibles. Neocapritermes also have soldiers with asymmetrical mandibles, but in Planicapritermes the left mandible forms an angle of less than $90^{\circ}$ at the proximal third, while in Neocapritermes the left mandible forms an angle over $90^{\circ}$ at the proximal third (Constantino 2002).

Of the two species of Planicapritermes, only $P$. planiceps had its worker described, as this caste was missing in the type series of $P$. longilabrum. The description of the digestive tube of P. longilabrum was based on soldiers (Constantino 1998). Here we describe the worker of $P$. longilabrum. In addition, we describe the nest of $P$. planiceps, as termite nests can be very complex structures, with taxonomic and phylogenetic 
information value (Constantino 1995), and so far no nest of Planicapritermes had been found.

Material of Planicapritermes planiceps and Planicapritermes longilabrum was collected in Vila Teotônio, Porto Velho, Rondônia state, Brazil (8'50'18”S, 6403'56”W) and is deposited in the invertebrate collection of Instituto Nacional de Pesquisas da Amazônia (INPA), Manaus, Amazonas, Brazil. The samples are maintained in vials containing $80 \%$ ethanol.

Dissections were made under a stereomicroscope following Constantino (1998), with forceps and entomological stylet. Four workers of $P$. longilabrum were dissected in a Petri dish containing $80 \%$ ethanol. The mandibles were dissected first, then the body wall and fat tissue were removed with tweezers, exposing the gut. The segment containing the insertion of Malpighian tubules was cut out and the gut content was removed through repeated pressure with tweezers. The enteric valve armature was exposed by a longitudinal section, mounted with polyvinyl alcohol - PVA on a microscope slide, and examined under a compound microscope.

Images were taken with a Leica DFC500 digital camera connected to a Leica MZ205 stereomicroscope linked to a computer with the Leica Application Site software with an Auto-Montage module included. The drawings were made in the vector-drawing program Inkscape Vector Graphics Editor 0.92. Terminology follows Noirot (2001) for the digestive tube and Fontes (1987) for the mandibles. Measurements were taken with an ocular micrometer following Roonwal's system (Roonwal 1970), when applicable: HW, head capsule width; HL, head capsule length until the end of the labrum; PW, mean pronotum width; HT, length of the hind tibia.

\section{Planicapritermes longilabrum Constantino, 1998}

Soldier (Figure 1a-b) (described by Constantino 1998).

Measurements of three soldiers (mm): HW average 1.24 (range 1.22-1.25); HL 1.72 (1.7-1.74); PW 0.71 (0.7-0.72); HT 0.77 (0.77-0.79).

\section{Worker (Figure 1c-e)}

Head capsule yellowish with long bristles over the dorsal surface (Figure 1c-d). Fontanelle slightly noticeable. Postclypeus moderately inflated with few long bristles. Labrum with long scattered bristles. Antennae with 13 articles. Articles: I > II < III, and the following gradually increasing in length and width. Left mandible with an apical tooth smaller than the first + second marginals; third marginal present. Right mandible with apical tooth of the same size as the first marginal; second marginal undeveloped; molar plate lacking ridges (Figure 2e). Thorax whitish; pro-, meso- and metanotum with few long bristles on edges. Procoxae with few short bristles on the external face; protibia densely covered

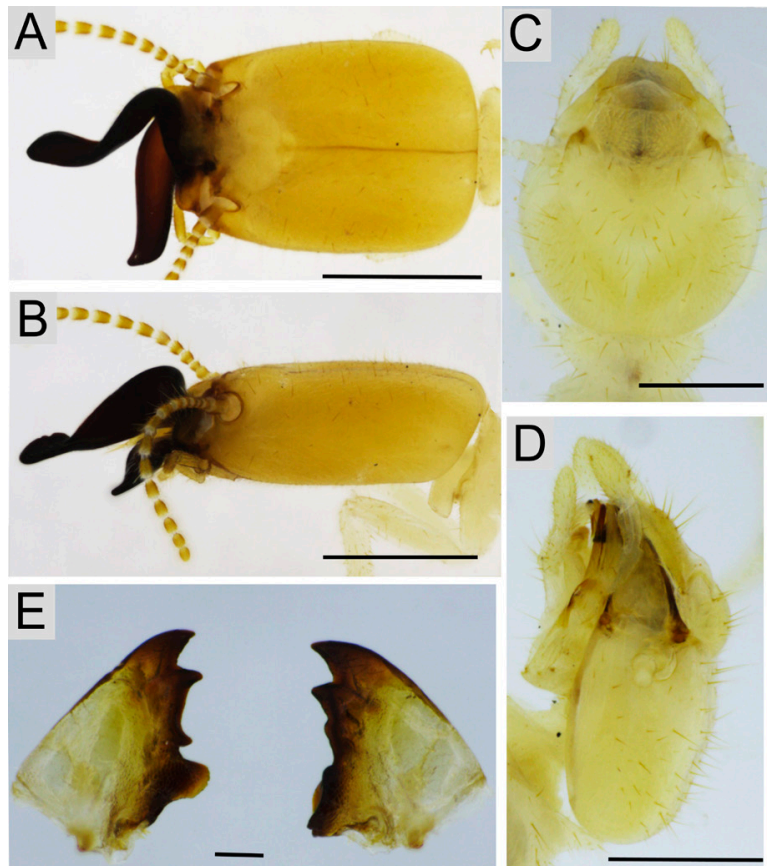

Figure 1. Soldier and worker of Planicapritermes longilabrum. A - Head of soldier in dorsal view; B - Head of soldier in profile; C - Head of worker in dorsal view; $D$ - Head of worker in profile; $E-$ Mandibles in dorsal view. Scale bar: $A-B=1 \mathrm{~mm}$ $\mathrm{C}-\mathrm{D}-\mathrm{E}=0.5 \mathrm{~mm}$. This figure is in color in the electronic version.
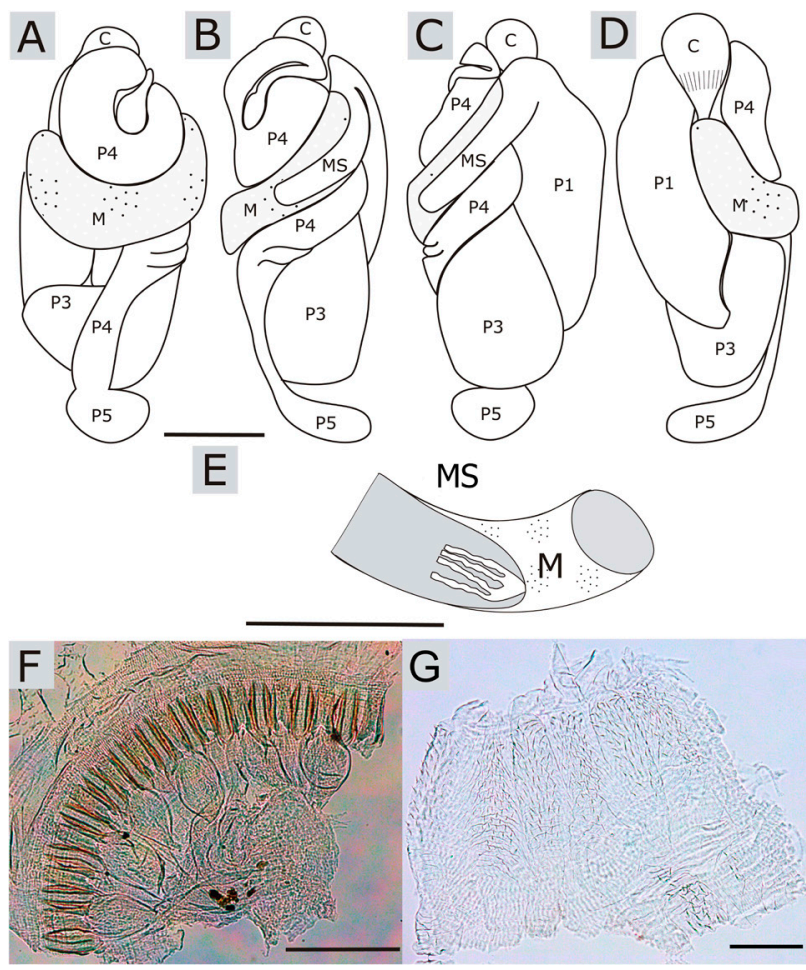

Figure 2. Digestive tube of worker of Planicapritermes longilabrum. A - Dorsal view; $B$ - Right view; C - Ventral view; D - Left view; E - Insertion of Malpighi tubules; F - Gizzard; G - Enteric valve. C, crop; G, gizzard; M, mesenteron; P1, first proctodeal segment; $P 2$, enteric valve; $P 3$, paunch; $P 4$, colon; $P$, rectum; $M S$, mixed segment. Scale bar: $A-E=0.5 \mathrm{~mm} ; F=0.2 \mathrm{~mm} ; G=0.1 \mathrm{~mm}$. This figure is in color in the electronic version. 
by long bristles. Abdomen translucid, tergites and sternites covered by many bristles of different sizes.

Digestive tube (Figure 2a-g). Gut forming a dense and long mass. Crop located between P1 and P4, funneling into the gizzard (Figure 2d). Gizzard only visible in left lateral view (Figure 2d); pulvillar belt with six pulvilli of the first order, six pulvilli of the second order; columnar belt with six folds of the first order, six of the second order and 12 of the third order; the ornamentation of the gizzard is well developed, both columns and pulvilli (Figure 2f). Mesenteric tongue long and external to the mesenteric arch. Two pairs of Malpighian tubules inserted at the same point as the mesenteron. Ileum parallel to the longitudinal body axis, longer than mesenteron; in ventral view, beginning at the left side of the anterior region and ending at the left side of the posterior region, where it connects with the paunch. The connection between ileum and paunch visible in the left lateral view (Figure 2d). Paunch globular, connecting to the colon in right lateral view by isthmus (Figure 2b). Enteric valve with six cushions conspicuous and symmetrical, each cushion with many spines distributed uniformly on the surface of the valve, with a proximal ring of cushions in the lower right corner (Figure 2g). Colon with the same width as the mesenteron. In dorsal view, colon C-shaped above the mesenteron, partially involving the final portion of the paunch. Folds present on colon surface of all dissected specimens, located posteriorly to the mesenteron and anteriorly to the rectum connection, not visible only in the left lateral view (Figure 2d).

Measurements of 17 workers $(\mathrm{mm})$ : HW average 0.86 (range 0.85-0.88); HL 1.02 (0.95-1.09); PW 0.46 (0.40.56); HL 0.79 (0.69-0.77).

Material examined: 3 soldiers and 17 workers of one sample labelled as: "Brazil, Rondônia, Usina Hidrelétrica de Santo Antônio, Vila de Teotônio. T2 500 (90) L D. 8050'18"S, 6403'56"W. Coleta manual. 21-31.vii.2014. R.A. Azevedo col".

Distribution and habitat: The specimens used in this work represent the first record of P. longilabrum for the state of Rondônia, approximately 2,000 km south from the first record of the species, in French Guiana. Both locations are within Amazon rainforest.

\section{Planicapritermes planiceps (Emerson, 1925)}

\section{Nest}

Two nests of $P$. planiceps were found in Rondônia, near the city of Porto Velho, at the margins of the Madeira River. Up until now, P. planiceps has been described as only found in decayed trunks on soil (Constantino 1999). The nests had an ellipsoid shape and were found at almost $15 \mathrm{~cm}$ underground (Figure 3). The nests had a carton texture and each contained soldiers, workers and one queen. Only a few species make

\section{Above the ground}

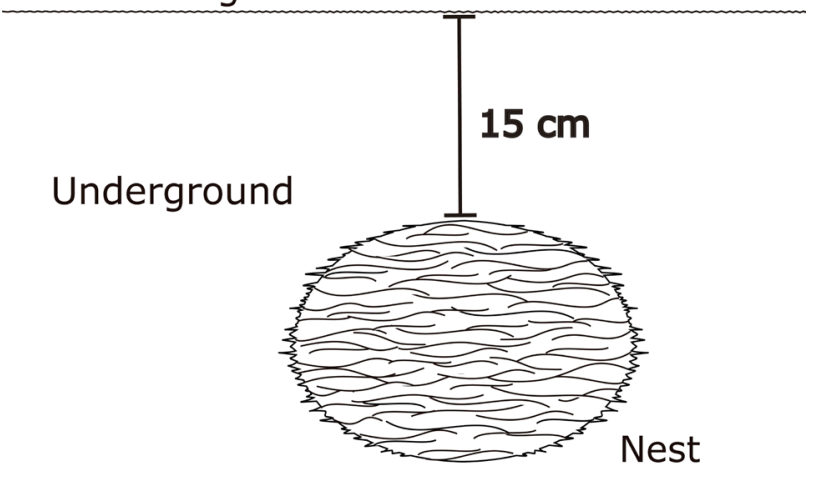

Figure 3. Schematic drawing of the cross section of a nest of Planicapritermes planiceps found in Rondônia state, Brazil.

carton nests underground (Noirot 1970), so this is an unusual characteristic of $P$. planiceps.

\section{Comparison between species}

Workers of $P$. longilabrum and $P$. planiceps have different shapes of the head capsule. In P. longilabrum, the head capsule is oval, whereas in P. planiceps the head capsule has parallel sides and width and length are equivalent. Planicapritermes longilabrum has bristles on the head capsule longer and in lower quantity than $P$. planicpes. The postclypeus in $P$. longilabrum is more inflated than in $P$. planiceps. Worker mandibles differ in size - in P. longilabrum, the left apical tooth has the same size as the left P1+2 (Figure 1e), whereas in P. planiceps, the left apical tooth is slightly shorter than the left P1+2, as illustrated by Krishna (1968).

The worker gut differs by the presence of folds in the colon in P. longilabrum (Figure 2a), which are absent in $P$. planiceps. In right lateral view, the mixed segment of $P$. longilabrum is longer and tubular (Figure 2b), while in $P$. planiceps it is shorter and broader. In P. longilabrum, the isthmus extends to the right, not visible in dorsal view, (Figure 2b), whereas in $P$. planiceps the isthmus is visible in dorsal view. The enteric valve of P. longilabrum has three cushion pairs in triradial symmetry, with long and dense spines disposed longitudinally, and a proximal ring of cushions in the lower right corner (Figure $2 \mathrm{~g}$ ), whereas $P$. planiceps has three cushion pairs, with short and sparse spines disposed longitudinally and the proximal ring of cushions in the lower right corner is absent.

Planicapritermes planiceps and P. longilabrum are similar in the connection of Malpighian tubules, with two paired tubules with the same insertion point at the mixed segment (Figure 2e). We also observed an intraspecific variation in the workers of P. longilabrum, as some specimens had a well noticeable crop in dorsal view, while others had the crop partially covered by the colon. 


\section{ACKNOWLEDGMENTS}

We acknowledge Instituto Nacional de Pesquisas da Amazônia (INPA) for research support and Fundação de Amparo à Pesquisa do Estado do Amazonas (FAPEAM) for a PRONEX project, call for proposals 016/2006, proc. \# 1437/2007, coordinated by Dr. José Albertino Rafael (INPA). RS and RAA acknowledge FAPEAM for their doctoral scholarships. RA acknowledges Conselho Nacional de Desenvolvimento Científico e Tecnológico (CNPq) for a PIBIC scholarship (2018/2019). We are grateful to Dr. Elizabeth Franklin for revising the English.

\section{REFERENCES}

Bourguignon, T.; Lo, N.; Šobotník, J.; Ho, S.Y.W.; Iqbal, N.; Coissac, E.; et al. 2017. Mitochondrial phylogenomics resolves the global spread of higher termites, ecosystem engineers of tropics. Molecular Biology and Evolution, 34: 588-597.

Constantino, R. 1995. Revision of the neotropical termite genus Syntermes Holmgren (Isoptera: Termitidae). Science Bulletin, 13: $455-518$.

Constantino, R. 1998. Description of a new Planicapritermes from Central Amazonia, with notes on the morphology of the digestive tube of the Neocapritermes-Planicapritermes group (Isoptera: Termitidae: Termitinae). Sociobiology, 32: 109-118.

Constantino, R. 1999. Chave ilustrada para identificação dos gêneros de cupins (Insecta: Isoptera) que ocorrem no Brasil. Papeis Avulsos de Zoologia, 40: 387-448.
Constantino, R. 2002. An illustrated key to Neotropical termite genera (Insecta: Isoptera) based primarily on soldiers. Zootaxa, 67: $1-40$.

Constantino, R. 2019. Termite database. (http://164.41.140.9/ catal/). Accessed on 02 Aug 2019.

Emerson, A.E. 1925. The termites of Kartabo, Bartica District, British Guiana. Zoologica, 6: 291-459.

Fontes, L.R. 1987. Morphology of the alate and worker mandibles of the soil-feeding nasute termites (Isoptera, Termitidae, Nasutitermitinae) from the Neotropical Region. Revista Brasileira de Zoologia, 3: 503-531.

Krishna, K. 1968. Phylogeny and generic reclassification of the Capritermes Complex (Isoptera, Termitidae, Termitinae). Bulletin of the American Museum of Natural History, 138: 261-324.

Noirot, C. 1970. The nests of termites. In: Krishna, K.; Weesner, F.M. (Ed.). Biology of termites. v.1. Academic Press, New York, p.73-125.

Noirot, C. 2001. The gut of termites (Isoptera) comparative anatomy, systematics, phylogeny. II. Higher termites (Termitidae). Annales de la Société Entomologique de France (Nouvelle Série), 37: 431-471.

Roonwal, M.L. 1970. Measurement of termites (Isoptera) for taxonomic purposes. Journal of the Zoological Society of India, 21: 9-66.

Snyder, T.E. 1949. Catalog of the termites (Isoptera) of the World. Smithsonian Miscellaneous Collections, 112: 1-490.

RECEIVED: $10 / 03 / 2020$

ACCEPTED: 01/01/2021

ASSOCIATE EDITOR: Ana Lucia Tourinho 